\title{
Fear, loathing and shale gas. The introduction of fracking to the UK: a case study.
}

\section{David McQueen}

\section{Introduction}

Energy, whether from oil, gas, coal, nuclear or renewables, has become one of the most controversial areas of public policy in recent years, generating intense debate and disagreement about the related economic, social and environmental choices faced by nation states in an era of global insecurity. Politically divisive arguments around which energy sources should be prioritised, invested in and supported have flared up in countries around the world. This has occurred against increasingly urgent calls for international action to reduce fossil fuel dependence and C02 emissions (IPCC 2014). Multinational energy companies have often been accused of failing to operate in a socially responsible manner (Balmer 2010; Tuodolo 2015; McQueen 2015) and the reputations of some of the largest global players have wilted under intense public scrutiny and a growing awareness of the impact of energy use and extraction on communities, ecosystems and the global climate. Such concerns have been widely publicised in relation to hydraulic fracturing or 'fracking' in the last decade in the US and Australia (see Bosworth 2014) which has intensified the debate in the United Kingdom around proposed on-shore shale gas exploration. In January 2013 David Cameron announced that local councils would be able to keep 100 per cent of business rates they collected from shale gas sites, 'worth up to $£ 1.7$ million a year for a typical site' because the government was 'going all out for shale' (Gov.uk 2013). The Prime Minister argued that, 'it will mean more jobs and opportunities for people, and economic security for our country' (Ibid). At a time of continuing conflict and instability in the Middle East, the prospect of fostering domestic energy supplies, investment and economic independence would appear an obvious policy choice, but as a KPMG (2011) report makes clear the shale industry has to surmount tremendous reputational hurdles, particularly in the UK and Western Europe where 'the industry needs to control reputational risk and turn public opinion around' (p.19).

Gas currently accounts for nearly half of the UK's total energy needs and around 30 percent of total electricity generated (DECC 2015). With North Sea gas production declining since 
2000 and imports of gas now exceeding exports, the Conservative government, led by David Cameron, is pressing ahead with what has been described as a second 'dash for gas' (Elkins 2012). Inspired by the 'shale revolution' in the United States, which has helped dramatically reduce global oil and gas prices and given a boost to the US economy, the British government has put in place a series of policies designed to encourage shale gas extraction and thereby, it is hoped, greater energy independence. These policies include halving the tax rates on early profits from shale gas, offering at least $£ 100,000$ in community benefits per well-site where hydraulic fracturing or 'fracking' takes place, and introducing industry-friendly regulatory changes, including the ability to drill beneath properties without the owner's permission (DECC 2016). This 'dash for gas' has been deeply controversial with environmentalists and civic groups, and since the first exploratory drilling site was established in Lancashire 2011 hundreds of environmental organisations and community groups have offered vociferous opposition to the policy (see Jones et al. 2013).

The conservative government has, until now, appeared to pay scant attention to these groups and it continues to vigorously promote the economic and environmental benefits of onshore gas exploration. The government argues that shale gas, with lower $\mathrm{CO} 2$ emissions than coal, can be a 'bridge' to renewables, as well as providing 65,000 jobs and energy security (DECC blog 2015). Those opposed to shale, or unconventional gas (UG), point to the dangers of widespread water and air pollution, increased earthquakes, drastically altered landscapes, various social and economic costs, and the wider impact on climate change of continuing our reliance on fossil fuels. This chapter provides an overview of a range of lobbying and public relations efforts by the oil and gas industry to portray shale gas exploration as safe and socially responsible in the face of determined and active opposition. It will outline some of the ways the industry has downplayed scientific doubts about the environmental and health impacts of fracking and related processes and successfully made its influence felt at the heart of government. It will also examine efforts to manage public perceptions of this highlycontested development through a media strategy which has been effective, at least in part, in shaping broadcast coverage of the debate.

\section{Definitions}


Shale gas is natural gas, mainly composed of methane, found in shale rock beds often located between 1,000 and 4,000 metres below the ground. The gas is released by fracturing or 'fracking' the shale by drilling a borehole down into the earth and then pumping a mixture of water, sand and chemicals at high pressure into the shale, cracking the rocks and allowing the gas to flow back through the borehole and to the surface (Jones et al 2015). This definition of high volume hydraulic fracturing (HVHF or 'fracking') is crucial because amongst many concerns expressed around shale gas exploration, the use of chemicals is amongst the most contentious. It is worth noting, for instance, that the government's public explanation of fracking often omits this aspect of the process, as in the following explanation found in the government's 'Guidance on Fracking' (Dec 2016): 'Hydraulic fracturing, known as fracking, is a technique used in the extraction of gas and oil from 'shale' rock formations by injecting water at high pressure' (p.2). This omission of the word 'chemicals', a key detail in the information offered to the public can be seen as symptomatic of a wider effort by the UK government and the fossil fuel industry to downplay potential hazards of fracking and present the case for shale gas exploration in the most positive light possible.

\section{Scientific disagreement}

In fact, scientists appear divided, or at least uncertain, over the safety of hydraulic fracturing and related activity. While there is neither the time nor space here to review the scientific disagreements in detail, an outline of the areas of dispute is required to make sense of the efforts to present univocal versions of the science around fracking. The disagreements can be summarised around seven alleged impacts of 'fracking' - a term used henceforth to cover the entire process of unconventional gas (UG) exploration and production. These seven impacts are: depletion and contamination of freshwater supplies; ground pollution and loss of biodiversity; the visual and physical effect on landscapes; increased seismic activity; air and noise pollution; the strain on local infrastructure and communities; and the wider contribution to man-made climate change.

A number of reports outline these and other threats in detail. For instance, The United Nations Environment Programme released a report in 2012 pointing out the dangers of methane leakage from fracking which has a Global Warming Potential (GWP) 'up to 72 times higher than CO2 over a 20 year period' (UNEP 2012, p.4). This and evidence of other environmental and health impacts led the report's authors to note that unconventional gas 
exploitation 'already includes instances of water contamination, leakages to soil, wide-scale land clearing and negative health impacts' and that 'increased extraction and use of UG is likely to be detrimental to efforts to curb climate change' (p.11-12). Whilst not ruling out fracking, it warns of 'unavoidable environmental impacts even if UG is extracted properly, and more so if done inadequately' (p.11).

A report for the European Commission published in 2012 also noted 'high risk for people and environment' in terms of water contamination and depletion, air pollution, risk to biodiversity, noise impacts and traffic (AEA 2012, p.v-vi). The report details how developing unconventional fossil fuel resources poses greater environmental risks than conventional gas development. Some recent studies have also argued that state support for unconventional oil and gas exploration is likely to be at the expense of the necessary huge investment in renewable sources of energy such as solar, wind and tidal required to reduce $\mathrm{C} 02$ emissions to acceptable levels (see Bosworth 2014). Hansen et al. (2012), for instance, argue that it would be 'foolhardy' for governments to encourage the development of any further fossil fuel extraction which may result in uncontrollable climate change. The danger underlined here and in other studies (see Tyndale Centre 2011) is that if states encourage unconventional oil and gas exploration our dependency on fossil fuels will simply be prolonged and the danger of runaway global warming will increase.

Induced seismic activity is another area of concern for those opposed to fracking. Scientific studies have clearly linked earthquakes with the underground disposal of wastewater from both conventional and unconventional oil and gas wells. Consequently, while hydraulic fracturing itself may not increase seismic activity, areas where fracking and associated wastewater disposal takes place have seen an enormous increase in tremors and quakes. The 2016 US Geological Survey observed, for example, that from 1950 to 2005, Oklahoma recorded an average of 1.5 earthquakes with a magnitude greater than 3.0 per year compared to 'several hundred M3.0+ earthquakes per year' in recent years (Petersen et al. 2016, p.14). In fact, the very short-lived exploratory fracking by Cuadrilla Resources in Lancashire in 2011 was halted due to widely reported earth tremors in the seaside town of Blackpool. While these were relatively minor, at 1.5 and 2.3 on the Richter scale, Cuadrilla later admitted, following an investigation they commissioned, that hydraulic fracturing was the most likely cause. 
While earthquakes, subsidence, noise, traffic and other threats to property values are of major concern, the dangers of water, air and land pollution from fracking have usually been most heavily prioritised in anti-fracking campaigns. These pollution issues have also been explored in numerous scientific reports and studies (see Jackson et al. 2015; TEDX 2016). The Chartered Institute of Water and Environmental Management (2012), for instance, stated that the UK 'should not encourage fracking as a part of our energy mix until there is more evidence that operations can be delivered safely' (cited Ritchie et al. 2014, p.3). A CHEM Trust report in 2015 entitled Chemical Pollution from Fracking warned of serious risks of local water, and land pollution and that fracking has the potential to massively impact the countryside and those who live in it - 'be it people, livestock or wildlife' (p.16).

Based on US figures, 2,400 000 gallons of fresh water, on average, per well is required to frack for shale gas, and the pressure on resources could be felt by communities that are vulnerable to water shortages and periodic droughts (see Harrison et al. 2014). As Jones et al. (2015) point out, these large volumes of water, mixed with a smaller volume of chemicals and lubricants, are pumped into boreholes where it is often difficult to predict their migration.

\section{Public opposition}

In light of these and other environmental and health concerns, public opposition to fracking in the US has increased significantly, rising from 40 percent to 51percent in 2015 alone (Gallup 2016). Numerous states, towns and cities around the world have voted for a moratorium on fracking, including the states of Vermont and Maryland in the US and Victoria and Tasmania in Australia. New York State voted to ban fracking after the release of a New York State Health Department (2014) report citing hundreds of peer-reviewed studies that pointed to chemical contamination, excess methane in water, surface spills, noise exposure and other health and environmental impacts. Many European countries have also shown little appetite for fracking with bans and moratoria in place in France, Germany, Netherlands, Czech Republic, Austria, Bulgaria, Scotland and Wales (Bloomberg 2014).

It may be that media coverage of fracking controversies and reports combined with the sustained efforts of anti-fracking activists are now having an impact on British public opinion. O'Hara et al.'s study of public attitudes in the UK to shale gas, for instance, shows a marked decline in support for fracking between 2013 and 2015 dropping from around 62 to 
47 percent. Shale gas, the authors observe, 'remains the energy source the UK public are least likely to want in the UK's 2025 energy mix' $(2015$, p.13). Their study shows that while shale was still considered a potentially cheap energy source that could bring significant economic benefits, growing numbers in the UK are opposed to its extraction, particularly amongst women who worry about the environmental impacts of fracking. The survey concludes that a growing proportion of the population do not want shale gas and that 'If the government pushes forwarded with its plans to fast track shale gas developments it must be prepared for significant levels of opposition from grass roots activists' (O'Hara et al. 2015, p.14). Evidence of this opposition has already appeared in mainstream media coverage and prolific social media coverage of protests around exploratory drilling in Balcombe in West Sussex, Upton in Cheshire, Barton Moss in Salford and on the Fylde coast in Lancashire.

\section{The shale gas campaign}

In 2013 the Institute of Directors identified the negative 'reputation' of fracking as one of the main barriers to enabling commercial production of on-shore shale gas to go ahead in the UK. They recommended that 'the industry itself needs to develop a social licence to operate' and that 'more needs to be done to gain the confidence of local communities' (cited Jones et al 2015, p.383). Efforts to build public confidence in shale gas as a socially responsible and environmentally safe energy have taken a number of forms. Shale gas developers, such as Cuadrilla Resources, Dart Energy, Igas Energy and Ineos, have engaged several public relations, including Westbourne Communications, PPS, Bell Pottinger and Burson-Marsteller (Spinwatch 2015), to develop 'comprehensive, coherent and co-ordinated media relations campaigns in an attempt to win hearts and minds at both the local and national levels' (Jones et al 2015, p. 387). The first element of this broad campaign had been underway for several years and involved gaining elite support amongst policy makers and academics. At the policy level the appointment of Lord John Browne Chairman, Board of Directors, Cuadrilla Resources (until April 2015) in June 2010 as the government's 'Lead Non-Executive Director' at the Cabinet Office (Parliament.UK 2016) enabled a number of shale gas industry employees, supporters and advisors to be employed within relevant departments. Lord Browne's role in appointing business leaders as Non-Executive Directors to the board of each government department included four appointees at the Treasury, three at DECC, four at DEFRA which oversees the Environment Agency and three in the Cabinet Office. 
In addition to these appointments, Lord Browne has lobbied the government for exemptions from the Environment Agency regulations for the shale industry and worked with Lord Smith (former Chair of the Environment Agency) to reduce consultation time on waste permits and intervene with a council on planning permission for Cuadrilla (Friends of the Earth 2015). In fact, lobbying is a somewhat insufficient term for what appears to be a partnership arrangement, or alignment of goals between government and industry around shale gas (see Cave and Rowell 2014 for an elaboration of the embedding of corporate interests in government). The lobbying watchdog Spinwatch (2015) lists dozens of government advisors with close connections to the fossil fuel and shale gas industries. The Spinwatch report also shows fourteen public relations firms 'hired by fracking companies', including Westbourne Communications, Weber Shandwick, Edelman, Burson Marsteller and Bell Pottinger with personnel embedded through various roles in government or political parties. While such connections are often hidden to all but the most diligent researcher, in other cases they are in full public view. The Task Force on Shale Gas (TFSG) was charged with providing the government and public with 'an independent and impartial examination of both the potential benefits and risks linked to shale gas extraction', but received $£ 650,000$ from the fracking industry, including the leading shale gas companies Cuadrilla, Centrica, French oil company Total, and chemical giant Dow. These sponsorship details were made public on the task force's web page and hence no claim of subterfuge could be alleged.

Nevertheless, the 'independence' of a shale-industry sponsored panel of four advised by five experts appears less certain on closer inspection. One of the panellists, Professor Ernest Rutter, wrote an article in The Guardian in 2013 defending fracking in answer to Green Party councillor's article on the topic. A second panellist Professor Nigel Brandon has held a research position with BP. The third, Emma Duncan, was the deputy editor of The Economist, a freemarket-oriented magazine that has championed fracking. The fourth, Lord Chris Smith is critical of the government's policy on renewables and carbon capture, but supportive of fracking. Amongst the five advisors, was former Greenpeace director Stephen Tindale, known for his controversial support of GM crops and fracking. According to the TFSG's constitution, also published on the website, 'the mission, goals, strategy and tactical plans for the Task Force' [is agreed] 'in consultation with a Secretariat provided by Edelman'. Public relations firm Edelman also provided the secretariat for The All Party Parliamentary Group on Unconventional Oil and Gas until 2014. Edelman, which operationalises and implements the TFSG mission and goals, represents Energy UK, a trade association representing 80 gas 
and electricity suppliers in the UK. Perhaps unsurprisingly, the task force panel concluded after a year of investigation that 'shale gas can be produced safely and usefully in the UK provided that the Government insists on industry-leading standards' and that exploratory drilling should begin (Task Force on Shale Gas 2015).

Lord Browne, a major stockholder and CEO of Cuadrilla, one of the funders of the shale gas taskforce, was, amongst other roles, chairman of the Royal Academy for Engineering until 2011. In 2012, the Royal Academy released a government-commissioned report on fracking. This was one of four key reports surveying the existing scholarship and assessing the risk of fracking in various domains which the government draws on to support the scientific case for shale gas. The Royal Academy report argued that the health, safety and environmental risks associated with fracking 'can be managed effectively in the UK as long as operational best practices are implemented and enforced through regulation' (The Royal Society and The Royal Academy of Engineering 2012, p. 4).

The Geological Society (2012) issued a report the same year broadly echoing the position of Royal Society and Royal Academy of Engineering that shale gas can be extracted safely 'assuming wells are properly constructed' and provided that 'best practice is rigorously applied under an appropriate regulatory regime which addresses environmental and societal concerns' (p.1). MacKay and Stone's (2013) report for the Department of Energy and Climate Change (DECC) argued that shale gas's overall carbon footprint was comparable to gas extracted from conventional sources. It underplayed the potential threat of methane release, stating, 'if adequately regulated, local GHG emissions from shale gas operations should represent only a small proportion of the total carbon footprint of shale gas, which is likely to be dominated by $\mathrm{CO} 2$ emissions associated with its combustion' (p. 3). The fourth report, Public Health England's (2014) recommendations on the potential public health impacts of exposures to shale-gas related chemical and radioactive pollutants concluded using similar language to the three reports mentioned above: 'currently available evidence indicates that the potential risks to public health from exposure to the emissions associated with shale gas extraction will be low if the operations are properly run and regulated. In order to ensure this, regulation needs to be strongly and robustly applied' (p.46).

One government report which is not cited by those promoting shale gas the is the notoriously redacted Department for Environment, Food \& Rural Affairs' Shale Gas: Rural Economy Impacts (2014) study which examined the 'potential economic, social and environmental 
impacts that are likely to be associated with an expansion in shale gas exploration'. The level of censorship (for want of a better word) can be measured by reading the recommendations (section 5) which are quoted in full here:

\section{REDACTED}

REDACTED

REDACTED

REDACTED

REDACTED

REDACTED

REDACTED

REDACTED

REDACTED

REDACTED

REDACTED (DEFRA 2014. p.13)

A year later the government was forced to publish the report in full after the Information Commissioner ordered the government to do so. The report provided some detail on likely water, noise, light and air pollution alongside possible short term benefits and long terms costs to the local economy, rents, house prices and insurance premiums. The covering note to the full report appeared to discredit, or at least undermine, the contents:

'This paper is an early draft of an internal document; it is not analytically robust. [...] Containing no new evidence, the paper simply refers to data from overseas studies which cannot be used to predict impacts in the UK with any degree of reliability'. (DEFRA 2015, p.1).

\section{Advocacy coalitions and sponsored research}

However, as Cairney et al. 2015. observe, 'evidence-based policy making' (EBPM) is a political process like any other, involving competition to decide what counts as evidence, 
how it should be evaluated, and what policymakers should do with it. They explain that while science plays an important role, 'the link between scientific information and policy is not linear or unproblematic' (p.3). As Cairney et al. 2015 remark, policymakers form 'advocacy coalitions' to join resources, coordinate their influence strategies, and translate their goals into policy. These contain, "people from a variety of positions (elected and agency officials, interest group leaders, researchers) who have similar policy beliefs and who coordinate activity over time (p.9). A 'network' of academic experts is a core component of the 'advocacy coalitions' which emerge from the drive to formulate and enact energy policy. It is unsurprising therefore, that some of the 'experts' on fracking most frequently cited in US and UK government reports emerge from fossil-fuel funded institutes and research centres. The issue of 'sponsored research' is acute in the US where most scientific work is directed toward finding more efficient and cheaper ways of getting shale gas out of the ground, rather than on the environmental and public health effects. However, with cuts to publicly funded research, industry sponsorship is a rapidly growing practice in the UK (see Lander 2013). According to research by investigative reporter Maeve McClenaghan (2015), 80 percent of the Russell Group Universities received funding from the fossil fuel industry totalling $£ 134,000,000$ between 2010-15. Just four, the University of Manchester, University of Cambridge, University of Oxford and Imperial University, received nearly 60 percent of this figure. The long term reputational impacts on higher education institutions and academic research more generally of industry-sponsored research grants are unclear, but the danger of perceived 'sponsorship bias' is that it may discredit much of the research funded, or part-funded, by the oil and gas industries. Reputational damage to Higher Education institutions of this kind has already occurred in the US several times. For example, New York State University's Buffalo Shale Resources and Society Institute (SRSI) was closed in November 2012 after allegations that a report on 'Environmental Impacts during Marcellus Shale Gas Drilling' was compromised by historical financial interests which may have influenced the authors' conclusions.

As Dr Stuart Parkinson, Executive Director of Scientists for Global Responsibility, points out leading oil and gas corporations now have a major influence on the teaching and research in many of the UK's top universities. They can, in his view, 'steer' research agendas towards fossil fuel related $R \& D$ rather than urgently needed alternatives and thereby undermine progress in tackling climate change (cited McClenaghan 2015). 
Research centres frequently cited by the government and in the media on the issue of fracking include Durham University's Energy Institute and the British Geological Survey based in Nottingham, which both receive sponsorship funds from a number of hydrocarbon and exploration companies. ReFINE - a 'fiercely independent' research consortium led jointly by Durham University and Newcastle University which focuses on the 'potential risks of shale gas and oil exploitation' is primarily funded by Centrica (which bought a 25 percent stake in Cuadrilla in 2013) and shale gas developers Ineos.

\section{The BBC's coverage}

How successful the strategy of funding research centres has been for the shale industry can be assessed by a surveying the BBC's coverage of the controversial extraction process. If the government and shale industry's 'trusted experts' dominate coverage this might be a decisive factor in the battle for the 'hearts and minds' of the general public. An Ofcom poll conducted in 2015 showed that half of people surveyed regard the BBC's news outlets, across TV, radio and online, as their 'single most important source of news' with the highest rating for accuracy and trustworthiness (Ofcom 2015, p.62). If industry-funded scientists are found to shape the scientific debate around shale gas on the $\mathrm{BBC}$, this could play a critical role in persuading a sceptical or undecided population of the merits of shale gas development.

To assess this, a sample of BBC stories on hydraulic fracturing was downloaded from the BBC website to offer a snapshot of the coverage of the debate. The search terms 'fracking' and 'science' were entered into the BBC's website (in March 2015) for the period $1^{\text {st }}$ January 2013 to $31^{\text {st }}$ December 2015 and any irrelevant results (such as stories about 'tracking') were deleted. The search was confined to the top twenty stories published between 2013-15 leading up the passing of the Infrastructure Bill in February 2015 and awarding of 93 Petroleum Exploration and Development Licences (PEDLs) after environmental assessment in December 2015. The onshore oil and gas licensing round was open to a period of six weeks public consultation from August 2015 on potential environmental impacts and was therefore a politically sensitive period in which hostile public opinion may have acted as a potential impediment to the government's plans to go 'all out for shale'.

So how is the science around fracking represented in this sample of BBC's coverage from 2013-15? The twenty online articles and on-demand radio broadcasts were analysed and 
contributors' views coded as either broadly in favour, neutral or against. While most articles made some effort to offer a brief summary of positions in favour and against fracking, the majority of contributions were broadly in favour, or presented a view that evidence-based science supported the case for shale gas development. This can be seen, at one level, by a simple tally of contributors over the sample with ten scientific sources, six industry sources and nine political sources broadly in favour of fracking, while just two scientists, five politicians and six environmental groups were cited as broadly opposing the case for fracking. The coding revealed five scientific sources and four political sources offered broadly neutral positions and that the British Geological Survey offered both neutral and broadly pro-fracking positions. Significantly, some of the sources contributed to more than one pro-fracking story. Professor Richard Davies was cited twice, as was Professor Quentin Fisher of the University of Leeds and Professor Zoe Shipton of Strathclyde University, (all frequent advocates for fracking in the media), while the British Geological Survey made contributions to a number of stories. All four sources have received research funding from oil and gas interests.

The range of contributors is of interest, with political sources outweighing scientific sources. Where party affiliation was identified, seven conservative sources dominated the pro-fracking argument with just one Labour, MSP Iain Gray, in favour. Political opposition to fracking came from four sources - two SNP and one cross-party (Environmental Audit Committee) and one unknown (planning officers at Lancashire County Council). The two scientists cited as broadly against fracking was Professor Martin Mayfield of the University of Sheffield (briefly) and Professor Kevin Anderson of Manchester University who wrote to BBC Inside Science to complain, and was interviewed about, unbalanced coverage on fracking and climate change. The impression created across the twenty articles was that scientific studies supported the case for fracking, with very little science offered in the case against. Arguments against fracking were mostly cited by various environmental groups such as Greenpeace (three times), Friends of the Earth, Frack Off, WWF Scotland and National Trust.

The sense that the scientific evidence lies on one side of the debate is heightened by some of the BBC's own reporter's commentaries. The following is taken from one of the twenty reports published on July $28^{\text {th }} 2014$, in which the BBC's environmental analyst Roger Harrabin is quoted: 
"If environmentalists succeed in stopping fracking in the UK by stirring up local objections they will actually make the greenhouse effect worse in the short term. This is because Britain will continue to use gas for heating and as a backup to capricious wind and solar electricity. If the industry can't get British gas it will import liquefied gas - and the energy needed to turn gas liquid makes it worse for the climate than home-produced gas."

The language employed here 'stirring up local opposition', 'capricious wind and solar electricity', 'worse for the climate' clearly favours the government and shale industry's narrative that shale can contribute to reducing the threat of climate change when, as we have seen, many evidence-based scientific studies suggest the opposite may be true (Tyndale Centre 2011; UNEP 2012; Harrison et al. 2014).

An examination of two radio broadcasts amongst the twenty stories reveals further lack of impartiality on the science around fracking. The first story which emerges as no. 1 from the search for 'fracking' and 'science' on the BBC's homepage, was a broadcast by Inside Science on $26^{\text {th }}$ September 2013 - a 'fracking special' meant to 'really understand the science surrounding the controversies'. The presenter, Adam Rutherford 'sorts science fact from science fiction' by putting 'your frack FAQs to four experts'. We are first introduced to Kris Bone, a well engineering director at iGas who is given five of the 15 minute feature to explain how the process worked from a coal-bed methane well in Warrington in Cheshire. Bone reassures listeners that 'fracking is not a new process' and has been around in the UK 'for at least 30 years' and used at around 200 onshore wells already: 'What is new is that it is in the deeper shales, which is a relatively new process in the UK'. Rutherford then introduces four experts who address some of the 'anxieties expressed by the public about fracking'. These are Professor Richard Davies from the Energy Institute; Dr David Rotherie, from the Open University; Professor Zoe Shipton, from the University of Strathclyde; and Professor Mike Stephenson from the British Geological Survey. These experts effectively dismiss concerns about water pollution and depletion, earthquakes and climate change. For instance, Richard Davies argues that 'the risk of contamination from fracking itself is incredibly low. There is not a single proven example of fracking causing contamination of groundwater'. David Rotherie supports this view, stating 'I don't think people's domestic water is at risk'. Zoe Shipton, also argues that the 0.1-0.2 percent chemicals found in fracking slickwater were 
safe and could be compared to, for instance, the scale inhibitor found in your kettles and that these could be safely captured and treated on site.

Richard Davies addressed the issue of water scarcity and admitted the issue 'depends where you are' (the risk in Southern England and Karoo desert in South Africa was greater than in the North of England), but that the proposed water consumption for fracking was a tiny percentage of overall national consumption in the UK. On climate change, Dave Rotherie, makes the case that domestic gas would create less $\mathrm{C} 02$ emissions than importing gas from abroad, and that shale gas is a 'very good stop gap' [...] 'otherwise we are going to be buying gas from the Russians for the next few decades'. Finally, on the issue of earthquakes, Mike Stephenson from the British Geological Survey admitted that the test drilling in Lancashire had probably caused very small tremors, but that, fracking, could actually 'save us from larger earthquakes, rather than causing earthquakes'.

In another Inside Science broadcast devoted partly to 'dispelling myths' around fracking on $11^{\text {th }}$ June 2015, after a vote by European MEPs for a moratorium on fracking, the two scientists interviewed were Justin Rubinstein from the US Geological Survey and Zoe Shipton (again) from Strathclyde University. The introduction to the interview sets out the concern clearly: 'There is no doubt that in the US, earthquake activity has rocketed in the last decade', but Justin Rubenstein argues that:

'the increase in earthquakes certainly correlates with human activity and the increase does correlate with fracking, but correlation is not causation. We really don't think many of these earthquakes are directly related to fracking. Maybe in the order of 5-10 percent of these earthquakes are attributable to fracking. The process that we think is related to these earthquakes is a process called waste water disposal. And this is water that comes out when you're pulling out oil or gas'.

The presenter Adam Rutherford, puts aside the 5-10 percent of cases that may be caused by hydraulic fracturing directly and comments:

'Well that's very interesting [...] it is based on gas mining I suppose, but it is not actually fracking that is causing that increase'. 
This interpretation depends on the narrowest definition of fracking as only the actual cracking of rocks deep beneath the earth's surface, rather than the entire process around unconventional gas extraction which includes, in the US at least, pumping water at high pressure, which stresses well integrity and underground waste water disposal.

Zoe Shipton, from Strathclyde University, argues that because waste water injection is 'unlikely' to be allowed, seismic events will be small and 'difficult to feel'. Returning to the MEP's largely 'symbolic' vote in support of a moratorium on fracking the presenter asks:

Is this a mistake? Is this a vote in the sway of popular opinion rather than evidence-based policy?

Zoe Shipton replies:

People are often not driven by the science. We can inform people about the science as much as we like, but the thing which makes people make their own minds up is their own values, fears and their concerns. There have been a number of reports including one by the Royal Society and Royal Academy of Engineering, that I was involved in, that have looked at the issues around environmental safety. The reports have largely found, or almost unanimously found, that this industry can be managed in a safe way if it is regulated properly and that the regulations in the UK are fit for purpose'

\section{Conclusion}

The BBC's charter requires that it offers balance and impartiality in the reporting of news and current affairs. In the case of reporting the scientific complexities and debates around fracking, it appears that the BBC is falling short of its obligations. The proposed introduction of fracking in the UK has so far passed the legislative hurdles and gained media and mainstream political support from the major parties. The government and sections of the media continue to frame shale gas as 'the cleanest fossil fuel' (DECC 2013, cited Jones et al. 2015). However, opposition to fracking continues to grow, and it may be that efforts to suppress dissenting scientific evidence by the government, the shale industry and the media 
will only amplify opposition and increase resistance to new technology. The various scientific doubts and uncertainties about fracking have not prevented the shale industry, the UK government and the BBC from presenting an optimistic and simplistic science-based case for unconventional gas. If shale gas exploration proceeds as planned in the UK, any evidence of negative impacts on communities, particularly accidents or contamination of water supplies in such a densely populated island will only mobilise greater and more intense opposition to the shale industry and any government or group of experts attempting to defend it.

The danger is that a one-sided, industry-funded presentation of science research may affect not only the reputation of fossil fuel industries, but academic institutions and values as well. In this respect the shale industry has fallen short of its Corporate Social Responsibility obligations to respect the views and livelihoods of communities and stakeholders in relation to the extraction of unconventional gas. Retreating behind narrow definitions of 'fracking', attempting to steer research and manage the debate in the media alongside intensive lobbying operations in the government may ultimately backfire and exacerbate public distrust of politicians, the mainstream media and the fossil fuel industry. A careful consideration of the impacts of continued hydrocarbon exploration (and particularly 'unconventional' oil and gas) on the environment, on communities and on long-term economic prosperity around the world at a time of growing climate insecurity is urgently required. This must remain a priority for any realistic discussion of corporate social responsibility - and is one that should be engaged with urgently by all organisations currently engaged in the promotion of shale gas development. 


\section{Bibliography}

AEA., 2012. Support to the identification of potential risks for the environment and human health arising from hydrocarbons operations involving hydraulic fracturing in Europe. Accessed March 28, 2016, http://ec.europa.eu/environment/integration/energy/pdf/fracking\%20study.pdf

Balmer, John M.T. “The BP Deepwater Horizon debacle and corporate brand exuberance”. Journal of Brand Management. 18 (2) 2010: 97-104.

Bloomberg. "Fracking in Europe: fighting the revolution". Last modified September 17, 2014. Accessed March 29 2016: http://www.bloombergview.com/quicktake/fracking-europe

Bosworth, T. "Unconventional and Unburnable: Why going all out for Shale Gas is the Wrong Direction for the UK's Energy Policy”. Issues in Environmental Science and Technology: Fracking 39 (2014) 199-221.

Cairney, Paul., Manuel Fischer, and Karin Ingold. "Hydraulic fracturing policy in the UK: coalition, cooperation and opposition in the face of uncertainty." In book chapter prepared for the edited book Mapping Political Landscapes of Hydraulic Fracturing, undated, [Online] available at htps://paulcairney. files. wordpress.com/2015/01/cairney-fischer-ingoldfrackingin-the-uk-for-zurich-workshop-23-jan-2015.pdf, accessed on May, vol. 12. 2015.

Cave, Tamasin., and Andy Rowell. A Quiet Word: Lobbying, Crony Capitalism and Broken Politics in Britain. London: The Bodley Head, 2014.

CHEM Trust. "Fracking pollution: how toxic chemicals from fracking could affect wildlife and people in the UK and EU" (2015). Accessed March 20 2016:

http://www.chemtrust.org.uk/wp-content/uploads/chemtrust-fracking-briefing-june2015.pdf

Department of Energy and Climate Change (DECC). UK Energy Statistics, Q2 2015. (2015) Accessed March 23, 2016, https://www.gov.uk/government/uploads/system/uploads/attachment_data/file/463016/Press_ Notice_September_2015.pdf

Department of Energy and Climate Change blog (DECC blog). 2015. Shale gas - an inconvenient truth for the anti-fracking lobby. Accessed March 23, 2016, 
https://decc.blog.gov.uk/2015/09/23/shale-gas-an-inconvenient-truth-for-the-anti-frackinglobby/

Department of Energy and Climate Change (DECC). Guidance on fracking: developing shale oil and gas in the UK. (2016) Accessed March 24, 2016, https://www.gov.uk/government/publications/about-shale-gas-and-hydraulic-fracturingfracking/developing-shale-oil-and-gas-in-the-uk

Department for Environment, Food \& Rural Affairs (DEFRA). "Shale Gas Rural Economy Impacts" (2014) Accessed March 23, 2016, https://www.gov.uk/government/uploads/system/uploads/attachment_data/file/408977/RFI67 51_Draft_Shale_Gas_Rural_economy_impact_paper.pdf

Department for Environment, Food \& Rural Affairs (DEFRA). "Draft Shale Gas Rural Economy Impacts” [Unredacted] (2015). Accessed March 23, 2016, https://www.gov.uk/government/uploads/system/uploads/attachment_data/file/440791/draftshale-gas-rural-economy-impact-report.pdf

Desmog. "Frack The Public: UK Shale Gets US Style PR Makeover". (2015) Accessed March 24, 2016, http://www.desmog.uk/2015/01/06/frack-public-shale-uk-gets-us-style-pr$\underline{\text { makeover }}$

European Commission. “Climate Action: Paris Agreement”. (2015) Accessed March 232016 http://ec.europa.eu/clima/policies/international/negotiations/paris/index_en.htm

Elkins, Paul., 2012. The UK's new dash for gas is a dangerous gamble. In: New Scientist. 6 December. Accessed March 23, 2016, https://www.newscientist.com/article/dn22594-theuks-new-dash-for-gas-is-a-dangerous-gamble/

Friends of the Earth. "Revealed: secret Government-Industry plans to circumvent fracking opposition”25th January (2015). Accessed March 24, 2016, https://www.foe.co.uk/blog/revealed-secret-government-industry-plans-circumvent-frackingopposition

Gallup. “Opposition to Fracking Mounts in the U.S”. 30 March. (2016) Accessed March 23, 2016, http://www.gallup.com/poll/190355/opposition-fracking-mounts.aspx 
The Geological Society. "Shale Gas and Fracking". (2012) Accessed on 23 ${ }^{\text {rd }}$ March, 2016, https://www.geolsoc.org.uk/Policy-and-Media/Resources/Shale-Gas-and-Fracking

Gov.uk. Local councils to receive millions in business rates from shale gas developments. $13^{\text {th }}$ January (2013). Accessed March 19, 2016, https://www.gov.uk/government/news/local$\underline{\text { councils-to-receive-millions-in-business-rates-from-shale-gas-developments }}$

Hansen, James., Sato, Makiko., Russell, Gary. and Kharecha, Pushker. "Climate sensitivity, sea level and atmospheric carbon dioxide". Philosophical Transactions of the Royal Society A: Mathematical, Physical and Engineering Sciences, vol. 371, issue 2001, (2013) 2012029420120294. Accessed March 20, 2016, http://arxiv.org/abs/1211.4846

Harrison, Gwen., Parkinson, Stuart. and McFarlane, Gary. "Shale gas and fracking: examining the evidence”. Scientists for Global Responsibility (SGR) and the Chartered Institute of Environmental Health (CIEH). (2014). Accessed March 23, 2016, http://www.sgr.org.uk/sites/sgr.org.uk/files/SGR-CIEH-Shale-gas-bfg.pdf

IPCC, 2014: Climate Change 2014: Synthesis Report. Contribution of Working Groups I, II and III to the Fifth Assessment Report of the Intergovernmental Panel on Climate Change [Core Writing Team, R.K. Pachauri and L.A. Meyer (eds.)]. IPCC, Geneva, Switzerland. Accessed March 19, 2016, http://www.ipcc.ch/report/ar5/syr/

Jackson, R, Lowry, E, Pickle, A, Kang, M, DiGiulio, D, \& Zhao, K. 'The Depths of Hydraulic Fracturing and Accompanying Water Use Across the United States', Environmental Science \& Technology, 49, 15, (2015) 8969-8976.

Jones, Peter., Hillier, David., Comfort, Daphne. "Fracking and public relations: rehearsing the arguments and making the case”. Journal of Public Affairs. Vol. 13, 4 (2013) 1479-1854.

Jones, P., Hillier, D. and Comfort, D. "The contested future of fracking for shale gas in the UK: risk, reputation and regulation". In World Review of Entrepreneurship, Management and Sustainable Development, Vol 11, No.4 (2015) 337-390.

KPMG. Shale Gas a global perspective. (2011) Accessed March 13, 2016, https://www.kpmg.com/Global/en/IssuesAndInsights/ArticlesPublications/Documents/shalegas-global-perspective.pdf 
Lander, Ric. Knowledge and power: fossil fuel universities. Platform, People \& Planet and 350.org. (2013) Accessed March 26, 2016, https://peopleandplanet.org/dl/fossilfree/knowledge-power-report.pdf .

MacKay, David., Stone, Timothy. "Potential Greenhouse Gas Emissions Associated with Shale Gas Extraction and Use”. Department of Energy and Climate Change (DECC) (2013) Accessed March 28, 2016,

https://www.gov.uk/government/uploads/system/uploads/attachment_data/file/237330/MacK ay_Stone_shale_study_report_09092013.pdf

McClenaghan, Maeve. "Investigation: Top universities take $£ 134 \mathrm{~m}$ from fossil fuel giants despite divestment drive". Greenpeace Energy Desk. (2015) Accessed March 14 2016, http://energydesk.greenpeace.org/2015/10/23/data-top-universities-take-134m-from-fossilfuel-giants-despite-divestment-drive/

McQueen, David. "CSR and new battle lines in online PR war: a case study of the energy sector". In: Ana Adi, Ana., Crowther, David and Grigore, Georgiana (eds) Online CSR Corporate Social Responsibility in the Digital Age. (Developments in Corporate Governance and Responsibility, Volume 7) (2015) Emerald Group Publishing Limited, p.99 - 125.

New York State Health Department. A Public Health Review of High Volume Hydraulic Fracturing for Shale Gas Development. Accessed March 24, 2016, https://www.health.ny.gov/press/reports/docs/high_volume_hydraulic_fracturing.pdf

Ofcom. "News consumption in the UK: research report" (2015) $15^{\text {th }}$ December. Accessed March 27, 2016, http://stakeholders.ofcom.org.uk/binaries/research/tvresearch/news/2015/News_consumption_in_the_UK_2015_report.pdf

O’Hara, Sarah., Humphrey, Mathew., Andersson-Hudson, Jessica and Knight, Wil., 2015. Public perception of shale gas extraction in the UK: two years on from the Balcombe protests. University of Nottingham. http://bettersociety.net/images/Public\%20Perceptions \%20of\%20shale\%20gas \%20in\%20the \%20UK\%20sept131015MH.WK.JA-H.pdf [Date accessed: 17 March. 2016].

Parliament.UK., 2016. Lord Browne of Madingley. http://www.parliament.uk/biographies/lords/lord-browne-of-madingley/2172 [Date accessed: 17 March. 2016]. 
Petersen, Mark., Mueller, Charles., Moschetti, Morgan., Hoover, Susan., Llenos, Andrea., Ellsworth, William., Michael, Andrew., Rubinstein, Justin., McGarr, Arthur., and Rukstales, Kenneth., 2016. 2016 One-Year Seismic Hazard Forecast for the Central and Eastern United States from Induced and Natural Earthquakes. U.S. Geological Survey, Reston, Virginia. Available at: http://pubs.usgs.gov/of/2016/1035/ofr20161035.pdf [Date accessed: 30 March. 2016].

Public Health England., 2014. Potential Public Health Impacts of Exposures to Chemical and Radioactive Pollutants as a Result of the Shale Gas Extraction Process. https://www.gov.uk/government/uploads/system/uploads/attachment_data/file/332837/PHECRCE-009_3-7-14.pdf

Ritchie, Heather., Lloyd, Greg., Griffiths, Philip., 2014. A fracking good time? A planned approach to energy resilience in the $U K$ and Ireland. Paper presented to the Association of European Schools of Planning (AESOP) Annual Congress 2014. "From control to coevolution”, University of Utrecht \& University of Delft, July $9-12$.

Spinwatch., 2015. Access all areas: Westminster's (vast) fracking lobby exposed. $29^{\text {th }}$ April. Available at: http://www.spinwatch.org/index.php/issues/climate/item/5765-access-all-areasfrackers-lobbyists-and-the-revolving-door [Date accessed: 10th January 2016].

Task Force on Shale Gas., 2015. Final Conclusions and Recommendations. https://www.taskforceonshalegas.uk/news-and-events/final-conclusions-andrecommendations [Date accessed: 10th February 2016].

TEDX., 2016. Chemicals in Oil and Gas Operations - Peer-reviewed Papers. TEDX The Endocrine Disruption Exchange. http://www.endocrinedisruption.org/chemicals-in-naturalgas-operations/peer-reviewed-articles [Date accessed: 24th March 2016].

The Royal Society and The Royal Academy of Engineering., 2012. Shale gas extraction in the UK: a review of hydraulic fracturing. http://www.raeng.org.uk/publications/reports/shalegas-extraction-in-the-uk [Date accessed: 18th February 2015].

Tuodolo, Felix., 2015. Corporate Social Responsibility: Between Civil Society and the Oil Industry in the Developing World. ACME: An International E-Journal for Critical Geographies, [S.1.], v. 8, n. 3, p. 530-541, mar. 2015. ISSN 1492-9732. <http://ojs.unbc.ca/index.php/acme/article/view/850/706>. [Date accessed: 25 March. 2016]. 
Tyndale Centre., 2011. Shale gas: an updated assessment of environmental and climate change impacts.

http://www.tyndall.ac.uk/sites/default/files/coop_shale_gas_report_update_v3.10.pdf [Date accessed: 20 March. 2016].

UNEP., 2012. Gas fracking: can we safely squeeze the rocks? Global Environmental Alert Service (GEAS) November. http://www.unep.org/pdf/UNEP-GEAS_NOV_2012.pdf [Date accessed: 28 March. 2016].

\section{Author note}

David McQueen is a lecturer in Politics, Media and PR at Bournemouth University. His research interests include public relations, news and current affairs, political communications and media management. He is currently researching various lobbying and 'greenwashing' campaigns by the fossil fuel industry and the presentation of fracking in the news.

\section{Abstract (218 word)}

The controversial practice of hydraulic fracturing or 'fracking' as practiced in the US has offered the promise of energy independence, a climate friendlier 'bridge' to renewable energy than coal, and an economic boom for those states that have taken advantage of the new shale oil and gas extraction techniques. At the same time, fracking is linked with widespread water and air pollution, increased incidence of earthquakes, the splitting of communities and a drastically altered landscape in many regions. How has the proposed introduction of fracking in the UK fared in light of these concerns? What role has science played in the battle for public opinion fought by the shale industry and its opponents? As part of a range of evidence explored, this study examines the BBC's coverage of the fracking controversy and scientific research around shale exploration leading up to the introduction of the Infrastructure Act and the public consultation on proposed extraction licenses in England in 2015. It considers the growth of civil opposition to fracking and efforts by the fossil fuel industry to manage such opposition, including the use of intensive public relations and lobbying activities. Finally, the 
chapter reflects on the Corporate Social Responsibility dimension to the controversy and the dangers for social cohesion and democratic engagement in light of recent developments in this area.

\section{Abstract (125 words)}

The controversial practice of 'fracking' as practiced in the US has offered the promise of energy independence, a climate-friendlier 'bridge' to renewable energy than coal, and a much needed economic boost. At the same time, fracking is linked with widespread water and air pollution, increased incidence of earthquakes, split communities and drastically altered landscapes. How has the proposed introduction of fracking in the UK fared in light of these concerns? What role has science played in the battle for public opinion fought by the shale industry and its opponents? This chapter examines efforts by the shale industry to 'win hearts and minds', including the use of intensive public relations including academic funding and lobbying activities, and assesses their impact on media coverage of the controversy. 